\title{
Between Fear and Confidence. The influence of Feedback on a Student's Self-Perceived Image
}

Adina O. Câmpean, Horia Corcheș 


\title{
Between Fear and Confidence. The influence of Feedback on a Student's Self- Perceived Image
}

\author{
Adina O. Câmpean ${ }^{\mathrm{a}}$, Horia Corcheș ${ }^{\mathrm{b}}$ \\ ${ }^{a, b}$ Doctoral School “Education, Reflection, Development”, Babes-Bolyai University Cluj-Napoca, 7 Sindicatelor Street, 400029, Romania \\ *Corresponding author: adina.campean@gmail.com
}

\section{Abstract}

Keywords:

influence of positive feedback;

student's self-perceived image;

implications of fear in the teaching

process; role models; strategies for

applying positive feedback.

\section{Schlüsselworte:}

Einfluss von positivem

Feedback; vom Selbst

wahrgenommenem Image des

Schülers; Auswirkungen von

Angst auf den

Unterrichtsprozess; Vorbilder;

Strategien zur Anwendung von

positivem Feedback.

Through this article, we intend to analyse one of the tools by which we can influence the projection of a positive self-perceived image on primary school students.

Our aim is to emphasise the importance of a conscious implementation of positive feedback, in teaching activities, designed to increase student involvement, to stimulate increased self-esteem, confidence and positive self-image.

\section{Introduction}

Romanian history, of the last century, has been tumultuous, vibrant, and familiar, for a long time, like the history of other European countries. The education system has been an integral part of these changes.

During the communist regime, the education system aligned itself with the regime-specific policy changes, which could be described as based on fear and strict rules. We do not support the idea that rules are a negative element in general, but in the context of the past regime, they stipulated building a "new man", obedient to the party ideology, afraid to express his opinion and trained to expose those who do it. This perspective is highlighted in the Final Report of the Presidential Commission for the Analysis of the Communist Dictatorship, 2006.

The 1990s brought about a radical change in politics, which led to the adoption of policies to reform the education system. In 2011, with the new Education Law, no. 1/2011, a new educational ideal was proposed, highlighting the "free, integral and harmonious development of human individuality, in the formation of autonomous personality and in assuming a system of values that are necessary for personal fulfillment and development, for the development of entrepreneurship, for active citizen participation in society, for social inclusion and for employment on the labor market". This can be consulted on the page https://edu.ro/sites/default/files/_fi\%C8\%99iere/Legi slatie/2020/LEN_actualizata_octombrie_2020.pdf.

Ideally, as teachers, we want to promote not only educational content, but also to coordinate the 'harmonious development' of the student, by building 
mental models through which students can translate what they think they know into everyday reality (Bain, 2004).

Whilst analysing this educational ideal, we must keep in mind that students will make decisions freely, will be harmoniously developed, balanced, and will assume value systems. Starting with value systems, this change of educational ideal could not change overnight the opinion of some adult generations; this would be the reformation of an entire system of beliefs and mentalities. For example, the following concepts are widespread and unfortunately accepted by many of the parents of students attending school: "My parents beat me, but now I am grateful for it." Other collected statements that reflect the same vision are: "the child must know about fear", "where the parent gives, grows up", "I made you, I kill you", "the beating is broken from heaven" etc. These commonly share the manifestation of authority based on fear. Conversely, at the other end of the spectrum are parents who are extremely permissive and believe that setting rules for their children hinders their harmonious development.

Therefore, teachers must carefully select the method by which they will aim to achieve their goals, given the family and social context from which the child comes. By correctly choosing the method, students' behavior and their attitudes, specifically human, can be developed in a positive way (Bocoș, 2017).

\section{Implications of fear in the teaching process}

The above statements as my parents beat me, but now I am grateful for it", "the child must know about fear", "where the parent gives, grows up", are verbalized meanings of adults. They reflect only a temporary submission, but the effects of parental education, in an authoritarian system, projected at least partially on their children, will be reflected in the child's behavior in the long run. As educators, we must keep in mind, and point out to those who adopt such a conception, that a child who is subjected to a treatment governed by fear will develop an egocentric vision. They will not learn compassion, no matter how much one tends to believe that he could understand suffering. In reality, the stimulus to which the child has been subjected makes him resilient in this sense and the treatment becomes "usual" for him, because he is trained in fear or dread.

Children will not be more respectful, but more fearful. The mentioned statements belong to a generation of adults and represent an unhealthy vision of some parents, and maybe even of some teachers, reflected in the treatment of their own children or students.

This introjection, "my parents beat me, but now I am grateful for it" will reflect on those around them and on future generations of children. This vision can reveal parents with a low self-image, who project their goals, in a negative way, through their children (Baumeister et al., 1996).

From a temporal point of view, the thirty years since the change of regimes are not enough for a radical change of mentality. We must point out that the idea that such a mentality of the parent is synonymous with an open communication in the teacher-parent relationship, is false. That mentality is not a control mode of the student, a relationship on which we can build a bridge between us and students in case of a conflict. Control over a situation will not be achieved in this way, because effective communication is certainly not built on a foundation based on fear.

There are several widespread opinions among parents and teachers that the child should learn, even out of fear. This type of learning, which is based on this meaning, has at least one visible negative side. Any student who will learn being motivated by this feeling, against a background of a fear or idea of danger, will associate in the future, the learning context with a negative feeling. When the student experiences fear in the future, this feeling is reactivated. For example, we do not touch something hot, because in our emotional memory we have reactivated an unpleasant memory. The fear- or the fright- is a feeling that can activate certain mechanisms that do not allow us to create a favourable environment to act freely, to become creative, to help others, to develop certain personal aspects, to have open and reflective attitudes, etc. For example, if a bear runs after us in the woods, we will not contemplate nature, but our goal will be to eliminate the danger. We deduce that a child who learns out of fear aims to obtain results, generating an inexplicable disadvantage for him, because he did not develop creativity to the same extent as a child who learns with pleasure. In conclusion, the student will focus on avoiding negative consequences, not trying new things, a situation that will lead to capping, a false balance, and the assumption that failure is attributed to him. 
Why should we care about this facet? Not only because the student, who comes from the mentioned environment, knows in principle to communicate only this way, but because we will not succeed in fulfilling one of the facets of the educational ideal, "harmonious development necessary for personal fulfillment and development and active citizen participation". The failure will not be of the child, nor of the parent who was not guided, but of us, of the teachers, who were passive in front of these experiences.

\section{Positive feedback, is it a recipe for success?}

Feedback is a response based on a set of information about the student's performance related to a time of his school development and progress. Feedback is not a personal opinion offered by a teacher but reflects an equilibrium between action and reaction, providing a clear and common goal for all.

The Romanian language has specific politeness rigors, namely through the existence of politeness pronouns and verbal forms of the second person plural so that, in the social context, communication is done through the aforementioned filter; this being reflected, even in the educational environment, within the interaction and communication relations between student and teacher. Regardless of age, due to the aforementioned contexts, language rigors and the parent-student relationship based on fear, means students are still afraid to express themselves freely and to support their opinions. This aspect will decrease the motivation to learn, resulting in counterproductive behavior.

In our opinion, positive feedback in any situation, at home, at school, at work, in society, improves, intensifies and accelerates productivity, motivation and maintains the desire to perpetuate well-being, in contrast to the fear I mentioned previously.

Positive feedback is the force that generates the mechanisms necessary for the cohesion and proper functioning of an individual or a team. When used correctly, it becomes a "coach" that motivates and engages all team members. But misused, or offered at the wrong time, can destroy the balance of the individual or group, while also affecting individual motivation and self-esteem, and subsequently the level of motivation of the group.

That is why the teacher, by knowing the effect it can produce through his actions, must choose activities that generate, primarily for students, a correct self-analysis, activities that create moments of social analysis, in a team, and only then to issue judgments of opinion on the activity of the students involved.

"Self-esteem is the evaluative component of the self and refers to emotional experience, the emotions that the person experiences when referring to their own person" (Constantin, 2004). Psychologists characterize self-esteem as an assessment we make of our self-worth as a person, and it can merge or identify with the feedback we receive from people with "authority" (Harris \& Orth, 2020).

Positive feedback builds a strong motivation to participate in activities, which in turn brings appreciation. Appreciation strengthens a positive selfimage, increases self-esteem, contributing to a cognitive, emotional and behavioral state that creates a self-perceived identity in a positive sense (Pajares, 2012).

The educational system, in the current context, must contribute to the development of the student for life and encourage individuality, creativity, initiative, autonomy and also to contribute to the general human progress.

Children are extremely receptive to role models. The way they are treated determines the way they behave. For many of them, school is the first experience outside the home. They will need a lot of attention and protection until they are confident enough to explore and participate in all the activities that society can offer.

Essential conditions for the efficiency of feedback would be, firstly, for the teacher to know the level of development of his students and to clearly establish his objectives. Secondly, for students to know very clearly where they stand and what level they have reached or are working towards.

It is easy to understand that properly used feedback, given at the right time, and received appropriately, increases motivation and involvement, and brings confirmation (or suggests directions for improvement) about how it was done. The child will learn, through age-appropriate methods, what he needs for his harmonious development at this age and to successfully cope with information-centered school requirements.

The schooling stage represents an important moment for stimulating the student's flexibility of thinking and creativity. According to cognitive 
psychology, it is important to know the internalised experiences of students and the motivating factors, because they are associated with different types of behaviors (Graham \& Weiner, 1996). In this sense, the teacher will insist on developing the child's interest in learning and on developing self-confidence. Interactive teaching processes will predominate, providing the context for active participation, individually and in groups, allowing the free expression of their own ideas and feelings. The feedback received can help students to self-evaluate, to create a constructive model and use it in accordance with the objectives set by mutual agreement with the factors involved.
What happens in "class" should take place in the form of a training suite, listed above, that not only has the role of developing critical thinking, but creates a pattern of analysis consistent with the teacher's thinking. The task chosen by the teacher impacts the student's performance, which is why the students' attributions will influence their actions (Graham \& Weiner, 1996). The student will resonate with the way the feedback is given and will look positively at the teacher's interventions. Thus, for teachers who have not formed a habit of using feedback as a teaching strategy, discovering its positive valences, in as varied contexts as possible, can find it a challenge. In Table 1 , we propose below a system of strategies for approaching feedback, which the teacher can use depending on the contexts he demands.

Table 1. Strategies for applying positive feedback effectively

\begin{tabular}{|c|l|l|}
\hline $\begin{array}{l}\text { Nr. } \\
\text { crt. }\end{array}$ & \multicolumn{1}{|c|}{ Strategy } & \multicolumn{1}{|c|}{ Description } \\
\hline 1. & „Sandwich" Feedback & $\begin{array}{l}\text { Compliment - making recommendations for improvement / improvement - } \\
\text { compliment. }\end{array}$ \\
\hline 2. & $\begin{array}{l}\text { Feedback provided on } \\
\text { time }\end{array}$ & $\begin{array}{l}\text { The feedback must be provided immediately. Feedback that is expected means lost } \\
\text { time. }\end{array}$ \\
\hline 3. & Individual feedback & $\begin{array}{l}\text { The individual needs of the student are identified through a self-analysis performed by } \\
\text { the student together with the teacher. Questions such as "what do you think?", "what } \\
\text { would you like to consolidate?", can be a resource in establishing an improvement plan } \\
\text { (Marzano, 2005). }\end{array}$ \\
\hline
\end{tabular}

4. Feedback provided by answering the four questions

$\checkmark$ What can the student do?

$\checkmark$ What can't the student do?

$\checkmark$ How does the student's activity compare to that of others?

$\checkmark$ How can the student do better?

5. Specific feedback

Providing punctual feedback on a specific skill or knowledge that can be used as praise.

6. „Check-in” feedback

It is offered constantly, on objectives and is meant to establish a learning pattern.

7. Individual meetings completed with the appreciation of a recently achieved goal

One-on-one positive conference lasting up to 10 minutes

\begin{tabular}{|c|l|}
\hline 8. & Short feedback \\
\hline 9. & $\begin{array}{l}\text { Progressively built } \\
\text { feedback / sequential } \\
\text { feedback }\end{array}$ \\
\hline
\end{tabular}

10. Work tasks performed

Verbalized by short encouragements (yes, that's right, try again).

Students receive feedback after each learning sequence.

Schedule of tasks for students, which at the time they are performed, are marked with 
\begin{tabular}{l|l} 
successively, with & a sticker.
\end{tabular}

displayed results

showing progress

11. The concept of "peer to peer"

12. "Guest" feedback

13. Taking notes and asking for feedback from the student

14. Correspondence notebook

15. Discussions between teacher and student and common analyzes about tests, papers or objectives from the beginning of the school year

16. Feedback on notes or post-its

17. Genuine praise

18. Time to say "I noticed"

19. The "yes, no" model
Feedback provided by the student to another student.

Another adult from outside will be involved in providing feedback.

The student takes notes, compares them in pairs to complete them, and then receives feedback in pairs from the teacher.

Specific tool where the teacher notes comments, puts stamps or other rewards.

Allow students to ask the necessary questions and have a relevant discussion, to analyze themselves correctly and to observe the real progress, where they are and what they want to buy (Marzano, 2005).
The teacher writes a brief comment for the student a note. It is not the most efficient use of a teacher's time, but it is extremely efficient in terms of the effect created.

The repetition of certain words specific to praise is avoided (bravo, excellent), without concretely mentioning the reason (Black \& William, 1998).

Often teachers do not have time to express the observation of progress. Recognizing the efforts a student makes is a solid foundation for positively influencing performance.

It can be demonstrated to students what we are looking for, for a positive impact. At the end, students will compare their work with the models offered and if necessary, a remediation plan is established with them.

The student's chance to "grade" the teacher, b giving an opinion about his activity.
We believe that we can conclude by stating that the use of feedback as a tool, in any context, by the fact that it generates satisfaction and well-being, is a strategy with a strong formative character. We found no logical explanation and no evidence that unconditional help from a teacher would not produce positive results in increasing students' self-esteem and a positive self-image. In obvious contrast, however, there is undoubtedly the manifestation of authority based on power, control and punishment.

Authors note: The authors had equal contributions to this article.
Adina O. Câmpean (Primary teacher) is currently a $\mathrm{PhD}$ student at the Doctoral School "Education, Reflection, Development" (domain: Sciences of Education), Babeș-Bolyai University, Cluj-Napoca, Romania, and associate teacher at Faculty of Psychology and Educational Sciences, Cluj-Napoca, Romania. She is also supporting the integration of children in difficult circumstances in collaboration with Peace Action, Training and Research Institute of Romania. Her professional and research interests are: children wellbeing and development, influence of positive role models, factors that affect students' motivation. 
Horia Corcheș teaches Romanian language and literature at the George Bariţiu National College in Cluj-Napoca and is currently a doctoral student at Babeș-Bolyai University. He is a school inspector, he has a permanent column in Dilema Veche magazine, where he writes articles on education. His research interests are oriented towards the didactics of reading, being concerned with the mechanisms by which reading identification is an essential stage in the process of understanding and interpreting the text, from the perspective of including said texts in the wider process of personal development. He is also concerned with the means by which non-formal education can intermingle, in the instructionaleducational process, with formal education.

\section{References}

Bain, K. (2004). What the Best College Teachers Do. Cambridge, Massachusetts: Harvard University Press.

Baumeister, R.F., Smart, L., \& Boden, J. M. (1996). Relation of Threatened Egotism to Violence and Aggression: The Dark Side of High Self-Esteem, Psychological Review, Jan., 103(1):5-33. Available at: https://doi.org/10.1037/0033-295x.103.1.5 (accessed at 18.02.2021).

Bocoş, M., 2017. Didactica disciplinelor pedagogice. Un cadru constructivist. Pitești: Editura Paralela 45.

Black, P., \& Wiliam, D. (1998). Inside the black box: Raising standards through classroom assessment. Phi Delta Kappan, October, pp. 139-148.
Constantin, T. (2004). Memoria autobiografică; definirea sau redefinirea propriei vieți. Iași: Editura Institutului European.

Graham, S., \& Weiner, B., 1996. Theories and Principles of Motivation. In D. C. Berliner, \& R. Calfee (Eds.). Handbook of Educational Psychology. New York: Macmillan.

Harris, M. A., \& Orth, U. (2020). The link between selfesteem and social relationships: A meta-analysis of longitudinal studies. Journal of Personality and Social Psychology, 119(6), 1459-1477. Available at: http://dx.doi.org/10.1037/pspp0000265 (accesed at 10.02.2021).

Pajares, F. (2012). Motivational role of self-efficacy beliefs in self-regulated learning. In D. H. Schunk \& B. J. Zimmerman (Eds.). Motivation and self-regulated learning. Theory, research, and applications ( $\left.1^{\text {st }} \mathrm{ed}.\right)$. New York: Routledge.

https://edu.ro/sites/default/files/_fi\%C8\%99iere/Legislatie /2020/LEN_actualizata_octombrie_2020.pdf (accesed at 15.01 .2021 ).

http://www.marzanoandassociates.com/pdf/ShortVersion. pdf (accesed at 10.11.2020).

https://www.wilsoncenter.org/sites/default/files/media/doc uments/article/RAPORT\%20FINAL_\%20CADCR.pdf (accesed at 10.02.2021). 